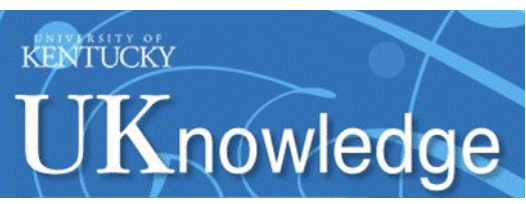

University of Kentucky

UKnowledge

12-1-2017

\title{
Buspirone Maintenance Does Not Alter the Reinforcing, Subjective, and Cardiovascular Effects of Intranasal Methamphetamine
}

Anna R. Reynolds

University of Kentucky, anna.reynolds@uky.edu

Justin Charles Strickland

University of Kentucky, justrickland@uky.edu

William W. Stoops

University of Kentucky, wwstoo0@email.uky.edu

Joshua A. Lile

University of Kentucky, jalile2@uky.edu

See next page for additional authors

Right click to open a feedback form in a new tab to let us know how this document benefits you. Follow this and additional works at: https://uknowledge.uky.edu/ps_facpub

Part of the Pharmacy and Pharmaceutical Sciences Commons, Psychiatry and Psychology Commons, and the Substance Abuse and Addiction Commons 


\section{Buspirone Maintenance Does Not Alter the Reinforcing, Subjective, and Cardiovascular Effects of Intranasal Methamphetamine}

Digital Object Identifier (DOI)

https://doi.org/10.1016/j.drugalcdep.2017.08.038

Notes/Citation Information

Published in Drug and Alcohol Dependence, v. 181, p. 25-29.

(C) 2017 Elsevier B.V. All rights reserved.

This manuscript version is made available under the CC-BY-NC-ND 4.0 license https://creativecommons.org/licenses/by-nc-nd/4.0/.

The document available for download is the author's post-peer-review final draft of the article.

Authors

Anna R. Reynolds, Justin Charles Strickland, William W. Stoops, Joshua A. Lile, and Craig R. Rush 


\title{
Buspirone maintenance does not alter the reinforcing, subjective, and cardiovascular effects of intranasal methamphetamine
}

\author{
Anna R. Reynolds ${ }^{a}$, Justin C. Strickland ${ }^{c}$, William W. Stoops ${ }^{b, c, d}$, Joshua A. Lile ${ }^{b, c, d}$, and \\ Craig R. Rush ${ }^{b, c, d}$ \\ aDepartment of Pharmaceutical Sciences, University of Kentucky College of Pharmacy, 789 \\ South Limestone, Lexington, KY 40536-0596, USA \\ bDepartment of Behavioral Science, University of Kentucky College of Medicine, 133 Medical \\ Behavioral Science Building, Lexington, KY 40536-0086, USA \\ 'Department of Psychology, University of Kentucky Arts and Sciences, 110 Kastle Hall Lexington, \\ KY 40506-0044, USA \\ dDepartment of Psychiatry, University of Kentucky College of Medicine, 245 Fountain Court, \\ Lexington, KY 40509, USA
}

\section{Abstract \\ Background-Medications development efforts for methamphetamine-use disorder have targeted central monoamines because these systems are directly involved in the effects of methamphetamine. Buspirone is a dopamine autoreceptor and D3 receptor antagonist and partial agonist at serotonin $1 \mathrm{~A}$ receptors, making it a logical candidate medication for methamphetamine- use disorder. Buspirone effects on abuse-related behaviors of methamphetamine have been mixed in clinical and preclinical studies. Experimental research using maintenance dosing, which models therapeutic use, is limited. This study evaluated the influence of buspirone maintenance on the reinforcing effects of methamphetamine using a self-administration procedure, which has}

Correspondence: Craig R. Rush, Ph.D., University of Kentucky Medical Center, Department of Behavioral Science, Lexington, KY, 40536-0086, Telephone: +1 (859) 323-6130, Facsimile: +1 (859) 257-7684, crush2@email.uky.edu.

Author Disclosures

Contributors

C.R. Rush, W.W. Stoops, and J.A. Lile developed the study concept and design. A.R. Reynolds and J.C. Strickland performed the data analyses and data interpretation under the guidance of C.R. Rush, W.W. Stoops, and J.A. Lile. A.R. Reynolds drafted the initial manuscript. All authors provided critical manuscript review. All authors approved the final version of the manuscript for submission.

Conflict of Interest

The authors declare no conflicts of interest.

Role of Funding Source

This research and the preparation of this manuscript were supported by grant numbers R21 DA0354810 (CRR) and T32 DA016176 from the National Institute on Drug Abuse and grant number 1247392 (JCS) from the National Science Foundation. These funding sources had no further role in study design, the collection, analysis, or interpretation of the data, writing of the report, or in the decision to submit the paper for publication.

Publisher's Disclaimer: This is a PDF file of an unedited manuscript that has been accepted for publication. As a service to our customers we are providing this early version of the manuscript. The manuscript will undergo copyediting, typesetting, and review of the resulting proof before it is published in its final citable form. Please note that during the production process errors may be discovered which could affect the content, and all legal disclaimers that apply to the journal pertain. 
predictive validity for clinical efficacy. The impact of buspirone maintenance on the subjective and cardiovascular response to methamphetamine was also determined.

Methods-Eight research participants ( 1 female) reporting recent illicit stimulant use completed a placebo-controlled, crossover, double-blind protocol in which the pharmacodynamic effects of intranasal methamphetamine $(0,15$, and $30 \mathrm{mg})$ were assessed after at least 6 days of buspirone $(0$ and $45 \mathrm{mg} /$ day) maintenance.

Results-Intranasal methamphetamine functioned as a reinforcer and produced prototypical stimulant-like subjective (e.g., increased ratings of Good Effects and Like Drug) and cardiovascular (e.g., elevated blood pressure) effects. These effects of methamphetamine were similar under buspirone and placebo maintenance conditions. Maintenance on buspirone was well tolerated and devoid of effects when administered alone.

Conclusions-These data suggest that buspirone is unlikely to be an effective pharmacotherapy for methamphetamine-use disorder. Given the central role of monoamines in methamphetamineuse disorder, it is reasonable for future studies to continue to target these systems.

\section{Keywords}

methamphetamine; buspirone; maintenance; subjective effects; cardiovascular effects

\section{Introduction}

Methamphetamine-use disorder is a significant public health problem. Nearly 1 million Americans over the age of 12 report past month methamphetamine use (Center for Behavioral Health Statistics and Quality, 2016). One-tenth of substance abuse treatment admissions reported amphetamines as their primary substance of abuse (Substance Abuse and Mental Health Services Administration, 2015). The cost (e.g., premature death, crime, and decreased productivity) of methamphetamine-use disorder is estimated at $\$ 23$ billion annually (Nicosia et al., 2009; Pasic et al., 2007; Shoptaw et al., 2009). Behavioral therapies (e.g., contingency management) modestly reduce methamphetamine use (e.g., Landovitz et al., 2015; Shoptaw et al., 2006; Smout et al., 2010). However, most patients are unable to sustain abstinence, suggesting novel treatment strategies such as pharmacotherapy are needed.

Medications development has targeted central monoamine systems (e.g., dopamine, serotonin, and norepinephrine) (e.g., Anderson et al., 2015; Brensilver et al., 2013; Rush et al., 2011) because these systems are directly involved in the effects of methamphetamine (Fleckenstein et al., 2000, 2007; Rothman and Glowa, 1995). Buspirone is a nonbenzodiazepine anxiolytic that functions as a dopamine autoreceptor and D3 receptor antagonist and partial serotonin 1A agonist (e.g., Heidbreder, 2008; Mahmood and Sahajwalla, 1999; Volkow and Skolnick, 2012). Prior studies examining the influence of acute buspirone treatment on the abuse-related behavioral effects of amphetamines have yielded mixed results. In rats, buspirone attenuated the locomotor effects of methamphetamine (Jackson et al., 1994) and cue-induced reinstatement (Shelton et al., 2013), but not the discriminative-stimulus effects (Munzar et al., 1999). In rhesus monkeys, buspirone attenuated the discriminative-stimulus effects of methamphetamine (Nader and 
Woolverton, 1994) but not methamphetamine self-administration (John et al., 2015). In the human laboratory, buspirone pretreatment enhanced some subjective effects of oral methamphetamine (e.g., Good Effects and Like Drug), but attenuated the cardiovascular effects (Pike et al., 2016). Those studies employed acute buspirone dosing, which does not reflect how buspirone would be used in the clinic. One pilot human laboratory study showed that buspirone maintenance is safe when combined with intravenous methamphetamine (Paterson et al., 2014), but a notable limitation of that study is the lack of a placebo control.

The purpose of this placebo-controlled human laboratory study was, therefore, to determine the initial efficacy, safety, and tolerability of buspirone maintenance for methamphetamineuse disorder. The primary outcome was drug self-administration given the predictive validity of self-administration procedures for clinical efficacy (Comer et al., 2008; Czoty et al., 2016; Haney and Spealman, 2008). The influence of buspirone on the subjective and cardiovascular effects of methamphetamine was also assessed.

\section{Materials and Methods}

\subsection{Participants}

Eight ( $\mathrm{N}=1$ female, 7 male) non-treatment seeking adult participants who were currently using an illicit stimulant completed this within-subjects, placebo-controlled study. The Institutional Review Board of the University of Kentucky (UK) Medical Center approved all procedures. Participants gave their written informed consent prior to study participation. Participants were compensated for their participation.

Participants underwent a comprehensive physical and mental health screening process (see Sevak et al., 2011). Participants were required to report recent illicit stimulant use confirmed by a positive urine screen and fulfill diagnostic criteria for stimulant abuse or dependence on a computerized version of the Structured Clinical Interview for the Diagnostic and Statistical Manual of Mental Disorders-IV (SCID). Potential participants were excluded if they had current or past histories of serious physical disease or psychiatric disorders, or reported physical withdrawal symptoms.

Participants ranged in age from 30-50 years (mean 41 years) and in weight from 55-104 kg (mean $85 \mathrm{~kg}$ ). Three were African-American, 3 were Caucasian, 1 was Caucasian Hispanic/ Latino, and 1 was African-American/Caucasian. Seven reported smoking tobacco cigarettes (range: 5-20 cigarettes/day; mean: 13 cigarettes/day). All participants reported lifetime illicit amphetamine use and past month cocaine use. One also reported past month amphetamine use. Participants reported recreational use of a range of substances (e.g., alcohol, caffeine, and marijuana).

\subsection{Study Procedures}

Participants were enrolled as inpatients at the UK Chandler Medical Center Clinical Services Core (CSC) for at least 22 days and completed 1 drug-free practice session and 6 experimental sessions. 
2.2.2. Drug Maintenance and Administration-Drug maintenance began on the day after the practice session and continued throughout the protocol. The order of drug maintenance conditions was counter-balanced. Drugs were administered in a double-blind fashion. Placebo and buspirone (target dose $=45 \mathrm{mg}$ /day) were administered orally at 0700 , 1500 , and 2300 hours. After completing the first maintenance period, participants were crossed over to the other maintenance condition (Figure 1). Buspirone was titrated (i.e., 5 $\mathrm{mg}$ three times daily for 1 day, $10 \mathrm{mg}$ three times daily for 2 days, and $15 \mathrm{mg}$ three times daily for the remainder of the maintenance period) up to the target dose. Doses were prepared by over-encapsulating commercially buspirone $\mathrm{HCl}$ tablets $(5,10$, or $15 \mathrm{mg})$ in size 0 capsules. Placebo capsules contained cornstarch only.

Methamphetamine doses $(0,10$, and $30 \mathrm{mg})$ were prepared by combining methamphetamine hydrochloride (National Institute on Drug Abuse, Research Triangle Park, NC) with lactose to equal $50 \mathrm{mg}$ powder. During methamphetamine administration, a nurse provided participants with the powder, a mirror, and a razor blade. They were instructed to divide the powder into 2 "equal" lines and insufflate one line of powder through each nostril using a 65-mm plastic straw within 2 minutes.

2.2.3. Experimental Sessions-Experimental sessions started at 0900 and lasted 8 hours. Urine and expired air breath samples were collected prior to each experimental session to confirm drug and alcohol abstinence, respectively. Participants occasionally tested positive for amphetamine, which coincided with experimental administration. In the morning, participants sampled the intranasal methamphetamine dose $(0,10$, and $30 \mathrm{mg}$; administered in random order) available later in session. In the afternoon, participants completed the modified-progressive ratio procedure and the portion of the dose earned on the task was administered an hour later. Subjective and cardiovascular effects were recorded prior to and at 15-minute intervals for 120 minutes following drug administration.

\subsection{Outcome Variables}

2.3.1. Drug Self-Administration-Participants had 10 opportunities to work to earn a portion of the drug sampled that morning $(0,10$, or $30 \mathrm{mg}$ intranasal methamphetamine). Participants completed a computerized modified progressive-ratio task by clicking the computer mouse to earn a portion of the total available dose. Participants were instructed that they could earn all or a portion of the sampled dose. Each completed ratio earned $1 / 10^{\text {th }}$ of the sampled dose. To complete the first ratio, participants were required to click 400 times. Each additional ratio increased by 100. Participants could terminate the task at any time by clicking a button labeled stop. The primary outcome variable was number of ratios completed.

2.3.2. Subjective Effect Questionnaires-Two subjective effect questionnaires were administered in a fixed order: 1) the Adjective Rating Scale (Oliveto et al., 1992) and 2) a Visual Analog Scale Drug Effect Questionnaire (Rush et al., 2003).

2.3.3. Cardiovascular Effects-Heart rate, blood pressure, temperature, and electrocardiography were recorded at regular intervals using an automated monitor. 
Sampling or self-administered doses were withheld if systolic and diastolic blood pressures were at or above $150 \mathrm{mmHg}, 100 \mathrm{mmHg}$ respectively, or if heart rate was at or above 100 bpm. None of the doses were withheld for exceeding these parameters.

\subsection{Data Analysis}

Effects with $p<.05$ were considered significant. Modified progressive-ratio data (i.e., number of drug choices) were analyzed with two-factor, repeated measure analysis of variance (ANOVA; IBM SPSS Statistics version 24, IBM Corporation, Armonk, NY) with methamphetamine $(0,10$, and $30 \mathrm{mg})$ and buspirone $(0$ and $45 \mathrm{mg})$ as factors. Fisher's Least Significant Difference (LSD) post hoc tests were used to interpret significant ANOVA outcomes for significant main effects or interactions. Comparisons were between active conditions and placebo (i.e., $0 \mathrm{mg}$ methamphetamine and $0 \mathrm{mg}$ buspirone). Subjective effects and cardiovascular data from sampling sessions were analyzed similarly as peak effect.

\section{Results}

\subsection{Drug Reinforcement}

A main effect of methamphetamine only was found for number of drug choices $\left(F_{2,14}=\right.$ $12.42, p=.001)$ on the modified progressive-ratio procedure. Active methamphetamine doses increased the number of drug choices relative to placebo regardless of maintenance condition (Figure 2).

\subsection{Subjective Effects Questionnaires}

3.2.1. Adjective Rating Scale-A main effect of methamphetamine only was detected for scores on the Stimulant subscale of the Adjective Rating Scale $\left(F_{2,14}=20.59, p<.001\right.$; data not shown). Active methamphetamine doses significantly increased these scores relative to placebo regardless of maintenance condition.

3.2.2. Drug Effect Questionnaire-A main effect of methamphetamine only was observed on 10 items from the Drug Effect Questionnaire: Active-Alert-Energetic, Any Effect, Good Effects, High, Like Drug, Willing to Pay For, Rush, Stimulated, Willing to Take Again, and Talkative $\left(F_{2,14}\right.$ values $>5.98, p$ values $<.013$; representative data are depicted in Figure 2). Across maintenance conditions, active methamphetamine doses generally increased ratings on these items relative to placebo with the exception that $10 \mathrm{mg}$ methamphetamine did not significantly increase ratings of Active-Alert-Energetic, Willing to Pay For, and Talkative.

\subsection{Cardiovascular Effects}

A main effect of methamphetamine only was found for systolic and diastolic blood pressure $\left(F_{2,14}\right.$ values $>3.86, p$ values $\left.<.05\right)$. Figure 2 shows that $30 \mathrm{mg}$ methamphetamine produced significant increases in systolic blood pressure relative to placebo. 


\section{Discussion}

This study demonstrated that methamphetamine functioned as a reinforcer, with near maximal responding observed for the highest dose tested. Methamphetamine also produced a constellation of prototypical stimulant-like subjective effects indicative of abuse potential (e.g., Good Effects and Like Drug) and elevated systolic and diastolic blood pressure. These effects are consistent with the type and magnitude of effects typically observed following methamphetamine administration by various routes (e.g., Hart et al., 2001; Kirkpatrick et al., 2012; Marks et al., 2016; Pike et al., 2016; Stoops et al., 2015), but was not impacted by buspirone maintenance.

These findings are concordant with preclinical studies showing that buspirone failed to attenuate methamphetamine choice (John et al., 2015) and methamphetamine discrimination in rats (Munzar et al., 1999). By contrast, buspirone attenuated locomotor effects (Jackson et al., 1994), cue-induced reinstatement (Shelton et al., 2013), and the discriminative-stimulus effects (Nader and Woolverton, 1994) of methamphetamine in other preclinical studies. In the human laboratory, acute buspirone administration enhanced some of the subjective effects of low doses of oral methamphetamine (e.g., Good Effects and Like Drug) (Pike et al., 2016). Mixed results have also been observed in behavioral studies that examined interactions between buspirone and cocaine (Bergman et al., 2013; Czoty and Nader, 2015; Gold and Balster, 1992; John et al., 2015, Mello et al., 2013). The reasons for these discrepancies are unknown, but could reflect differences between acute and maintenance dosing of dopamine antagonists on effects of psychomotor stimulants (Haney and Spealman, 2008) or route of psychomotor stimulant administration (e.g., intranasal, oral, or intravenous).

This study also assessed the safety and tolerability of buspirone maintenance, alone and in combination with methamphetamine. Buspirone was devoid of effects when administered alone. No subjects withdrew from the study due to study medications and no serious adverse events occurred. These data are consistent with prior reports showing that the combination of buspirone with methamphetamine (Pike et al., 2016; Paterson et al., 2014) and cocaine (Bolin et al., 2016) is safe and tolerable. These findings are also concordant with a past study demonstrating that buspirone alone does not engender subjective effects (Strickland et al., 2017).

A limitation of the present study is that a small sample size was enrolled. However, the reinforcing, subjective, and cardiovascular effects of methamphetamine were detected with medium to large effect sizes (i.e., ranging from .36 - .85) (Olejnik and Algina, 2000). Second, although self-administration outcomes are thought to best predict pharmacotheraputic efficacy compared to other laboratory-based screening procedures (Comer et al., 2008; Haney and Spealman, 2008), whether buspirone would alter other aspects of addiction (e.g., vulnerability to relapse) (Koob and Le Moal, 2001) is unknown. Considering the negative results with buspirone on cocaine use in the natural ecology (Moeller et al., 2001; Winhusen et al., 2014) and the present findings, buspirone would likely have limited efficacy for methamphetamine-use disorder. 


\section{Acknowledgments}

We would like to thank the expert staff of the University of Kentucky Laboratory of Human Behavioral Pharmacology for assistance in screening and running sessions with research participants in this study. We would also like to thank the Investigational Drug Services at the University of Kentucky for preparation of study medications

\section{References}

Anderson AL, Li SH, Markova D, Holmes TH, Chiang N, Kahn R, Campbell J, Dickerson DL, Galloway GP, Haning W, Roache JD, Stock C, Elkashef AM. Bupropion for the treatment of methamphetamine dependence in non-daily users: A randomized, double-blind, placebo-controlled trial. Drug Alcohol Depend. 2015; 150:170-174. [PubMed: 25818061]

Bergman J, Roof RA, Furman CA, Conroy JL, Mello NK, Sibley DR, Skolnick P. Modification of cocaine self-administration by buspirone (buspar(R)): Potential involvement of D3 and D4 dopamine receptors. Int J Neuropsychopharmacol. 2013; 16:445-458. [PubMed: 22827916]

Bolin BL, Lile JA, Marks KR, Beckmann JS, Rush CR, Stoops WW. Buspirone reduces sexual risktaking intent but not cocaine self-administration. Exp Clin Psychopharmacol. 2016; 24:162-173. [PubMed: 27254258]

Brensilver M, Heinzerling KG, Shoptaw S. Pharmacotherapy of amphetamine-type stimulant dependence: An update. Drug Alcohol Rev. 2013; 32:449-460. [PubMed: 23617468]

Center for Behavioral Health Statistics and Quality (CBHSQ). [Accessed 04.28.17] Results from the 2015 National Survey on Drug Use and Health: detailed tables. 2016. http://www.samhsa.gov/data/ sites/default/files/NSDUH-DetTabs-2015/NSDUH-DetTabs-2015/NSDUH-DetTabs-2015.pdf

Comer SD, Ashworth JB, Foltin RW, Johanson CE, Zacny JP, Walsh SL. The role of human drug selfadministration procedures in the development of medications. Drug Alcohol Depend. 2008; 96:115. [PubMed: 18436394]

Czoty PW, Nader MA. Effects of oral and intravenous administration of buspirone on food-cocaine choice in socially housed male cynomolgus monkeys. Neuropsychopharmacology. 2015; 40:10721083. [PubMed: 25393717]

Czoty PW, Stoops WW, Rush CR. Evaluation of the "pipeline" for development of medications for cocaine use disorder: A review of translational preclinical, human laboratory, and clinical trial research. Pharmacol Rev. 2016; 68:533-562. [PubMed: 27255266]

Fleckenstein AE, Gibb JW, Hanson GR. Differential effects of stimulants on monoaminergic transporters: Pharmacological consequences and implications for neurotoxicity. Eur J Pharmacol. 2000; 406:1-13. [PubMed: 11011026]

Fleckenstein AE, Volz TJ, Riddle EL, Gibb JW, Hanson GR. New insights into the mechanism of action of amphetamines. Annu Rev Pharmacol Toxicol. 2007; 47:681-698. [PubMed: 17209801]

Gold LH, Balster RL. Effects of buspirone and gepirone on i. v cocaine self-administration in rhesus monkeys. Psychopharmacology (Berl). 1992; 108:289-294. [PubMed: 1355922]

Haney M, Spealman R. Controversies in translational research: Drug self-administration. Psychopharmacology (Berl). 2008; 199:403-419. [PubMed: 18283437]

Hart CL, Ward AS, Haney M, Foltin RW, Fischman MW. Methamphetamine self-administration by humans. Psychopharmacology (Berl). 2001; 157:75-81. [PubMed: 11512046]

Heidbreder C. Selective antagonism at dopamine D3 receptors as a target for drug addiction pharmacotherapy: A review of preclinical evidence. CNS Neurol Disord Drug Targets. 2008; 7:410-421. [PubMed: 19128200]

Jackson DM, Johansson C, Lindgren LM, Bengtsson A. Dopamine receptor antagonists block amphetamine and phencyclidine-induced motor stimulation in rats. Pharmacol Biochem Behav. 1994; 48:465-471. [PubMed: 8090816]

John WS, Banala AK, Newman AH, Nader MA. Effects of buspirone and the dopamine D3 receptor compound PG619 on cocaine and methamphetamine self-administration in rhesus monkeys using a food-drug choice paradigm. Psychopharmacology (Berl). 2015; 232:1279-1289. [PubMed: 25327444] 
Kirkpatrick MG, Gunderson EW, Johanson CE, Levin FR, Foltin RW, Hart CL. Comparison of intranasal methamphetamine and d-amphetamine self-administration by humans. Addiction. 2012; 107:783-791. [PubMed: 22050030]

Koob GF, Le Moal M. Drug addiction, dysregulation of reward, and allostasis. Neuropsychopharmacology. 2001; 24:97-129. [PubMed: 11120394]

Landovitz RJ, Fletcher JB, Shoptaw S, Reback CJ. Contingency management facilitates the use of postexposure prophylaxis among stimulant-using men who have sex with men. Open Forum Infect Dis. 2015; 2:ofu114. [PubMed: 25884003]

Mahmood I, Sahajwalla C. Clinical pharmacokinetics and pharmacodynamics of buspirone, an anxiolytic drug. Clin Pharmacokinet. 1999; 36:277-287. [PubMed: 10320950]

Marks KR, Lile JA, Stoops WW, Glaser PE, Hays LR, Rush CR. Separate and combined effects of naltrexone and extended-release alprazolam on the reinforcing, subject-rated, and cardiovascular effects of methamphetamine. J Clin Psychopharmacol. 2016; 36:213-221. [PubMed: 27043121]

Mello NK, Fivel PA, Kohut SJ, Bergman J. Effects of chronic buspirone treatment on cocaine selfadministration. Neuropsychopharmacology. 2013; 38:455-467. [PubMed: 23072835]

Moeller FG, Dougherty DM, Barratt ES, Schmitz JM, Swann AC, Grabowski J. The impact of impulsivity on cocaine use and retention in treatment. J Subst Abuse Treat. 2001; 21:193-198. [PubMed: 11777668]

Munzar P, Laufert MD, Kutkat SW, Novakova J, Goldberg SR. Effects of various serotonin agonists, antagonists, and uptake inhibitors on the discriminative stimulus effects of methamphetamine in rats. J Pharmacol Exp Ther. 1999; 291:239-250. [PubMed: 10490910]

Nader MA, Woolverton WL. Blockade of the discriminative stimulus effects of d-amphetamine in rhesus monkeys with serotonin 5-HT(1A) agonists. Behav Pharmacol. 1994; 5:591-598. [PubMed: 11224238]

Nicosia N, Reardon E, Lorenz K, Lynn J, Buntin MB. The medicare hospice payment system: A consideration of potential refinements. Health Care Financ Rev. 2009; 30:47-59. [PubMed: 19719032]

Olejnik S, Algina J. Measures of effect size for comparative studies: Applications, interpretations, and limitations. Contemp Educ Psychol. 2000; 25:241-286. [PubMed: 10873373]

Oliveto AH, Bickel WK, Hughes JR, Shea PJ, Higgins ST, Fenwick JW. Caffeine drug discrimination in humans: Acquisition, specificity and correlation with self-reports. J Pharmacol Exp Ther. 1992; 261:885-894. [PubMed: 1602393]

Pasic J, Russo JE, Ries RK, Roy-Byrne PP. Methamphetamine users in the psychiatric emergency services: A case-control study. Am J Drug Alcohol Abuse. 2007; 33:675-686. [PubMed: 17891660]

Paterson NE, Vocci F, Sevak RJ, Wagreich E, London ED. Dopamine D3 receptors as a therapeutic target for methamphetamine dependence. Am J Drug Alcohol Abuse. 2014; 40:1-9. [PubMed: 24359505]

Pike E, Stoops WW, Rush CR. Acute buspirone dosing enhances abuse-related subjective effects of oral methamphetamine. Pharmacol Biochem Behav. 2016; 150-151:87-93.

Rothman RB, Glowa JR. A review of the effects of dopaminergic agents on humans, animals, and drug-seeking behavior, and its implications for medication development. Focus on GBR 12909. Mol Neurobiol. 1995; 11:1-19.

Rush CR, Stoops WW, Hays LR, Glaser PE, Hays LS. Risperidone attenuates the discriminativestimulus effects of d-amphetamine in humans. J Pharmacol Exp Ther. 2003; 306:195-204. [PubMed: 12676890]

Rush CR, Stoops WW, Lile JA, Glaser PE, Hays LR. Subjective and physiological effects of acute intranasal methamphetamine during d-amphetamine maintenance. Psychopharmacology (Berl). 2011; 214:665-674. [PubMed: 21072503]

Sevak RJ, Vansickel AR, Stoops WW, Glaser PE, Hays LR, Rush CR. Discriminative-stimulus, subject-rated, and physiological effects of methamphetamine in humans pretreated with aripiprazole. J Clin Psychopharmacol. 2011; 31:470_480. [PubMed: 21694622] 
Shelton KL, Hendrick ES, Beardsley PM. Efficacy of buspirone for attenuating cocaine and methamphetamine reinstatement in rats. Drug Alcohol Depend. 2013; 129:210-216. [PubMed: 23374566]

Shoptaw, S., King, WD., Landstrom, E., Bholat, MA., Heinzerling, K., Victorianne, GD., Roll, JM. Public health issues surrounding methamphetamine dependence. In: Roll, JR.Ling, W.Rawson, RA., Shoptaw, S., editors. Basic Science to Treatment. Guilford Press; New York: 2009. p. 143-156.

Shoptaw S, Klausner JD, Reback CJ, Tierney S, Stansell J, Hare CB, Gibson S, Siever M, King WD, Kao U, Dang J. A public health response to the methamphetamine epidemic: The implementation of contingency management to treat methamphetamine dependence. BMC Public Health. 2006; 6:214. [PubMed: 16919170]

Smout MF, Longo M, Harrison S, Minniti R, Wickes W, White JM. Psychosocial treatment for methamphetamine use disorders: A preliminary randomized controlled trial of cognitive behavior therapy and acceptance and commitment therapy. Subst Abus. 2010; 31:98-107. [PubMed: 20408061]

Stoops WW, Pike E, Hays LR, Glaser PE, Rush CR. Naltrexone and bupropion, alone or combined, do not alter the reinforcing effects of intranasal methamphetamine. Pharmacol Biochem Behav. 2015; 129:45-50. [PubMed: 25459104]

Strickland JC, Bolin BL, Romanelli MR, Rush CR, Stoops WW. Effects of acute buspirone administration on inhibitory control and sexual discounting in cocaine users. Hum Psychopharmacol. 2017:32.

Substance Abuse and Mental Health Services Administration, Center for Behavioral Health Statistics and Quality. [Accessed 04.28.17] Treatment Episode Data Set (TEDS): 2004-2014, national admissions to substance abuse treatment services. 2016. https://wwwdasis.samhsa.gov/dasis2/ teds_pubs/2014_teds_rpt_natl.pdf

Volkow ND, Skolnick P. New medications for substance use disorders: Challenges and opportunities. Neuropsychopharmacology. 2012; 37:290-292. [PubMed: 22157859]

Winhusen TM, Kropp F, Lindblad R, Douaihy A, Haynes L, Hodgkins C, Chartier K, Kampman KM, Sharma G, Lewis DF, VanVeldhuisen P, Theobald J, May J, Brigham GS. Multisite, randomized, double-blind, placebo-controlled pilot clinical trial to evaluate the efficacy of buspirone as a relapse-prevention treatment for cocaine dependence. J Clin Psychiatry. 2014; 75:757-764.

[PubMed: 24911028] 


\section{Highlights}

- The pharmacodynamic effects of methamphetamine during buspirone maintenance were determined.

- Methamphetamine functioned as a reinforcer and produced prototypic subjective effects.

- $\quad$ Buspirone and methamphetamine combinations were safe and tolerable.

- Buspirone maintenance did not change methamphetamine self-administration.

- Buspirone maintenance did not change methamphetamine subjective effects. 


\section{Experimental Timeline}

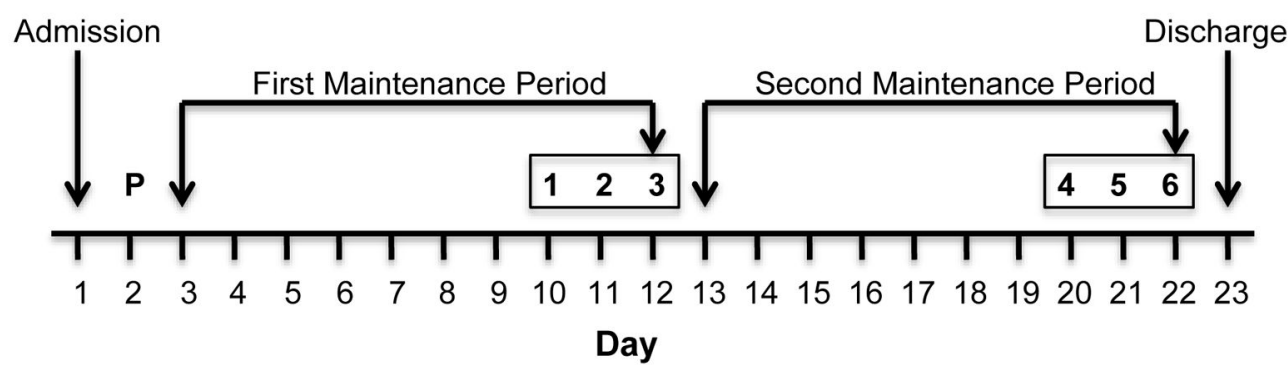

Figure 1.

Experiment timeline. The order of methamphetamine sampling doses was randomized and the order of buspirone maintenance was counter-balanced across participants. Boxed numbers (i.e., 1-6) on the top row denote experimental sessions. Numbers on the bottom row (i.e., 1-22) denote calendar days. 

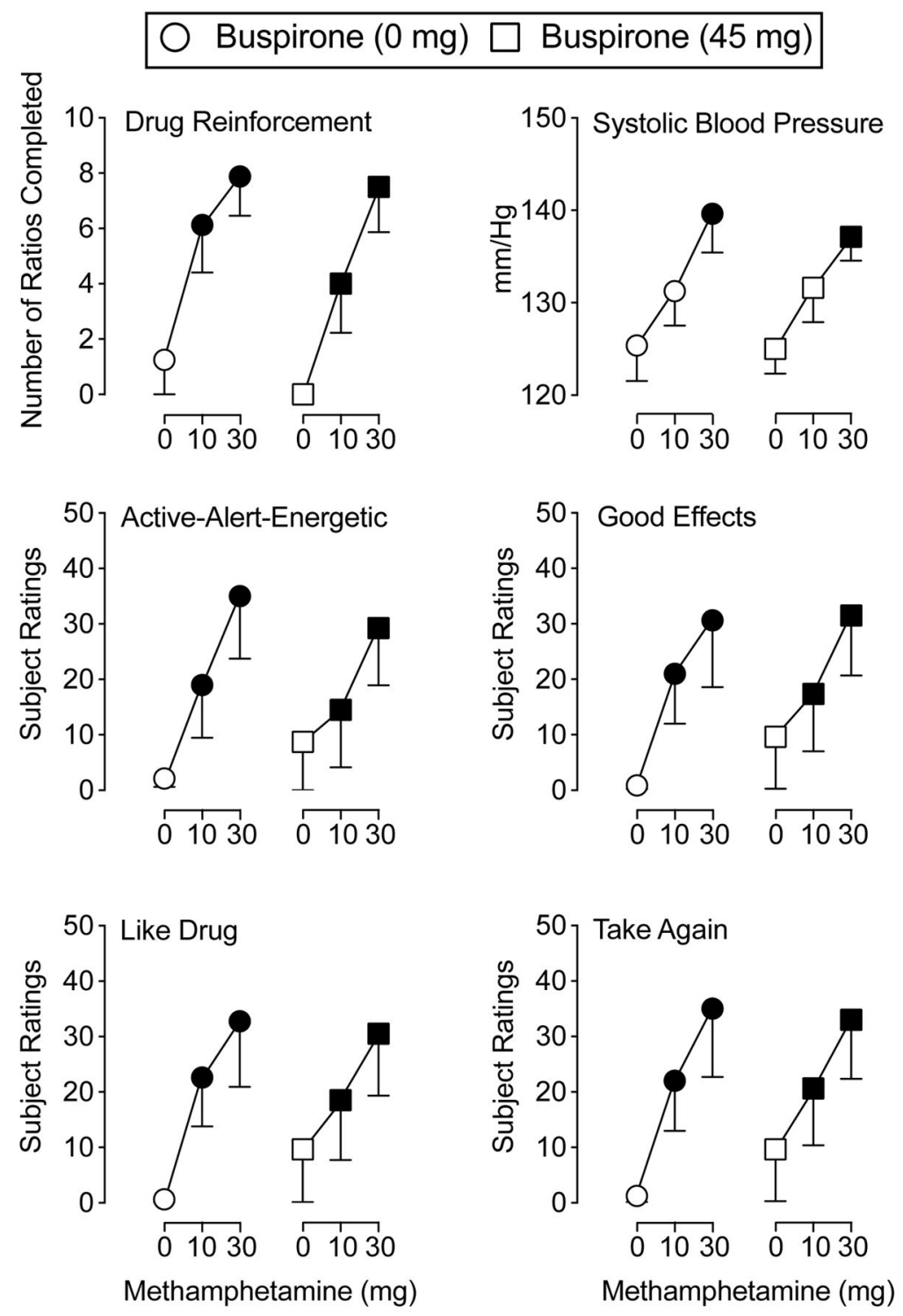

Figure 2.

The top left panel illustrates the number of ratios completed for methamphetamine (top left panel) during buspirone maintenance. The remaining panels demonstrate the peak effects of the sampling doses of methamphetamine during buspirone maintenance on systolic blood pressure (top right panel), and subject ratings of Active-Alert-Energetic (middle left panel), Good Effects (middle right panel), Like Drug (bottom left panel), and Willing to Take Again (bottom right panel). The $\mathrm{X}$-axis represents methamphetamine dose. For all panels, circles represent $0 \mathrm{mg}$ buspirone and squares represent $45 \mathrm{mg}$ buspirone. Filled symbols indicate a significant difference from placebo using Fisher's LSD post hoc test. Error bars represent standard error of the mean. $\mathrm{N}=8$ for all data points. 